\title{
Profil struma non toksik pada pasien di RSUP Prof. Dr. R. D. Kandou Manado periode Juli 2014-Juni 2016
}

\author{
${ }^{1}$ Sarah T. Tallane \\ ${ }^{2}$ Alwin Monoarfa \\ ${ }^{2}$ P. A. V Wowiling \\ ${ }^{1}$ Kandidat Skripsi Fakultas Kedokteran Universitas Sam Ratulangi Manado \\ ${ }^{2}$ Bagian Bedah RSUP Prof. Dr. R. D. Kandou Manado \\ Email: tallanesarah@gmail.com
}

\begin{abstract}
Struma or goiter is the most widely thyroid gland disease in the world that causes enlargement of the thyroid gland. This disease can be classified based on clinical, physiological, and anatomical alteration. If the function of the thyroid gland is normal it is called as non-toxic struma that involves many risk factors. This was a descriptive retrospective study using the medical records of all non-toxic struma patients hospitalized at Prof. Dr. R. D. Kandou Hospital Manado from July 2014 to June 2016. There were 38 non-toxic struma patients in this study distributed based on sex, age, morphology, sosioeconomy, region of residences, laboratory results, and therapy. Conclusion: The majority of the patients were females, aged 41-50 years old, diagnosed as non-toxic uninodular struma, middle to low class of socio-economy, living in lowland areas, laboratory result as euthyroid, and treated with surgery.
\end{abstract}

Keywords: struma, enlargement of the thyroid gland, normal

\begin{abstract}
Abstrak: Struma (goiter) merupakan penyakit kelenjar tiroid terbanyak di dunia yang menyebabkan pembesaran kelenjar tiroid. Penyakit ini dapat diklasifikasikan berdasarkan klinis, fisiologi, dan perubahan anatomi. Bila kerja kelenjar tiroid normal maka disebut struma non toksik dan melibatkan berbagai faktor risiko. Jenis penelitian ialah deskriptif retrospektif dengan menggunakan data rekam medik semua pasien rawat inap struma non toksik di RSUP Prof. Dr. R. D. Kandou Manado periode Juli 2014-Juni 2016. Terdapat 38 pasien struma non toksik yang didistribusi berdasarkan jenis kelamin, usia, perubahan anatomi, sosioekonomi, daerah tempat tinggal, hasil laboratorium, dan terapi. Simpulan: Majoritas pasien terdiri dari perempuan, usia 41-50 tahun, diagnosis struma non-toksik uninodusa, golongan ekonomi menengah ke bawah, tempat tinggal di dataran rendah, hasil pemeriksaan laboratorium cenderung eutiroid, dan terapi tindakan operatif.
\end{abstract}

Kata kunci: struma, pembesaran kelenjar tiroid, normal.

Penyakit tiroid terjadi bila terdapat gangguan sekresi hormon tiroid, pembesaran kelenjar tiroid, maupun keduanya. ${ }^{1}$ Di antara berbagai penyakit tiroid salah satunya dikenal dengan struma atau goiter yang merupakan penyakit kelenjar tiroid tersering di dunia. ${ }^{2}$ Struma bisa diklasifikasikan secara fisiologik menjadi eutiroid, hipotiroid, dan hipertiroid maupun secara klinik menjadi struma toksik dan non-toksik. Kedua tipe struma dapat diklasifikasikan juga berdasarkan perubahan bentuk anatomi tiroid menjadi struma nodusa non-toksik, struma nodusa toksik, struma difusa non-toksik, dan struma difusa toksik. ${ }^{3}$

Struma non-toksik paling sering diakibatkan kurangnya konsumsi yodium 
Tallane, Monoarfa, Wowiling: Profil struma non...

untuk jangka waktu lama (kronik)., Biasanya struma non-toksik menyerang individu yang bertempat tinggal pada daerah yang kondisi tanah dan air kurang kandungan yodium seperti daerah pegunungan. ${ }^{5}$ Beberapa faktor risiko lain untuk terjadinya struma non-toksik antara lain: jenis kelamin, usia, dan konsumsi obat-obatan tertentu, sedangkan ras tidak terlalu berpengaruh dibandingkan status ekonomi yang rendah di negara nonindustri yang berperan penting dalam kurangnya konsumsi iodium. $^{6-9}$

Wilayah daratan Kota Manado cukup unik karena mempunyai dua komponen yang mayoritasnya terdiri dari barisan pegunungan dan perbukitan di area bagian tengah, ketinggiannya mencapai sekitar 610 mdpl, namun di area kota hanya memiliki ketinggian 250 mdpl. Dataran rendahnya berada di sekitar tepi pantai. ${ }^{10}$ Penelitian ini bertujuan untuk mengetahui gambaran penyebaran penyakit struma non-toksik ini berdasarkan keunikan wilayah geografis Kota Manado dimana dataran tinggi dan dataran rendah terletak berdekatan beserta faktor-faktor risiko lainnya.

\section{METODE PENELITIAN}

Jenis penelitian ialah deskriptif retrospektif dengan memanfaatkan data sekunder dari Bagian Rekam Medik RSUP Prof. Dr. R. D. Kandou Manado. Subjek penelitian ini ialah semua pasien rawat inap yang didiagnosis struma non toksik selama periode Juni 2014-Juli 2016. Variabel penelitian ialah jenis kelamin, usia, perubahan anatomi, sosioekonomi, daerah tempat tinggal, hasil laboratorium, dan terapi.

\section{HASIL PENELITIAN}

Selama periode Juli 2014-Juni 2016, didapatkan 38 kasus struma non toksik yang dikelompokkan berdasarkan sebaran jenis kelamin (Tabel 1), usia (Tabel 2), perubahan anatomi (Tabel 3), kelas dirawat (Tabel 4), daerah tempat tinggal (Tabel 5), hasil laboratorium (Tabel 6), dan terapi (Tabel 7).
Tabel 1. Distribusi berdasarkan jenis kelamin

\begin{tabular}{ccc}
\hline Jenis kelamin & Total & \% \\
\hline Laki-laki & 6 & 15,8 \\
Perempuan & 32 & 84,2 \\
Total & 38 & 100 \\
\hline
\end{tabular}

Tabel 2. Distribusi berdasarkan usia

\begin{tabular}{ccc}
\hline Usia & Total & $\%$ \\
\hline$<10$ & 0 & 0 \\
11- 20 tahun & 1 & 2,60 \\
21-30 tahun & 5 & 13,20 \\
31-40 tahun & 8 & 21 \\
41-50 tahun & 9 & 23,70 \\
51-60 th & 8 & 21 \\
$>60$ tahun & 7 & 18,40 \\
Total & 38 & 100 \\
\hline
\end{tabular}

Tabel 3. Distribusi berdasarkan perubahan

\begin{tabular}{ccc}
\hline $\begin{array}{c}\text { Perubahan } \\
\text { anatomi }\end{array}$ & Jumlah & \% \\
\hline Uninodusa & 14 & 36,80 \\
Multinodusa & 13 & 34,20 \\
Diffusa & 5 & 13,20 \\
Nodusa & 6 & 15,80 \\
Total & 38 & 100 \\
\hline
\end{tabular}

Tabel 4. Distribusi berdasarkan kelas dirawat

\begin{tabular}{ccc}
\hline Kelas & Total & \% \\
\hline VIP & 0 & 0 \\
I & 12 & 31,60 \\
II & 1 & 2,60 \\
III & 17 & 44,70 \\
Tidak diketahui & 8 & 8,21 \\
Total & 38 & 100 \\
\hline
\end{tabular}

Tabel 5. Distribusi berdasarkan daerah tempat tinggal

\begin{tabular}{ccc}
\hline Tempat tinggal & Total & \% \\
\hline Dataran tinggi & 17 & 31,60 \\
Dataran rendah & 20 & 68,40 \\
Tidak diketahui & 2 & 5,26 \\
Total & 38 & 100 \\
\hline
\end{tabular}


Tabel 6. Distribusi berdasarkam hasil laboratorium

\begin{tabular}{cccccc}
\hline Jenis & Eutiroid & Hipotiroid & Hipertiroid & Total & \% \\
\hline T3 & 17 & 0 & 0 & 17 & 22,7 \\
T4 & 12 & 3 & 0 & 15 & 20 \\
FT3 & 4 & 0 & 5 & 9 & 12 \\
FT4 & 11 & 0 & 2 & 13 & 17,3 \\
TSH & 17 & 0 & 4 & 21 & 28 \\
Total & 61 & 3 & 11 & 75 & 100 \\
\hline
\end{tabular}

Tabel 7. Distribusi berdasarkan terapi

\begin{tabular}{ccc}
\hline Terapi & Jumlah & \% \\
\hline Operatif & 31 & 81,60 \\
Non operatif & 1 & 2,60 \\
Tidak diterapi & 6 & 15,80 \\
Total & 38 & 100 \\
\hline
\end{tabular}

\section{BAHASAN}

Pada penelitian ini ditemukan sebanyak 38 kasus struma non-toksik di RSUP Prof. R. D. Kandou Manado periode Juni 2014-Juli 2016.

Perempuan merupakan jenis kelamin yang paling sering terserang struma nontoksik dengan perbandingan antara penderita struma non toksik laki-laki dan perempuan sebesar 1:5. Pada penelitian sebelumnya perbandingan perempuan 1,24,3 kali lebih tinggi dibandingkan laki-laki, dan khususnya struma non-toksik diffusa, perbandingan penderita laki-laki dan perempuan ialah 1:4. ${ }^{11,12}$ Pada perempuan lebih banyak kebutuhan fisiologik terutama saat kehamilan, laktasi, menopause, dan pubertas yang mengakibatkan terjadinya ketidakstabilan hormon pada tubuh perempuan. Sifat tubuh yang sensitif terhadap perubahan akan bereaksi terhadap keadaan ini sehingga kekurangan hormon yodium sering menyebabkan gangguan pada sistem reproduksi perempuan tetapi tidak pada laki-laki. Populasi perempuan paling rentan terhadap kejadian struma non-toksik ialah pada saat hamil, terlebih saat fetus sudah berusia 16-17 minggu karena sudah dimulainya pembentukan kelenjar tiroid fetus yang mulai mengambil asupan yodium dari ibu. ${ }^{4}$

Berdasarkan Tabel 2, penderita struma non-toksik terbanyak pada golongan usia 41-50 tahun. Peningkatan angka kejadian setiap dekade terlihat pada struma nontoksik nodusa yang tidak tergolongkan dan struma non-toksik difusa. Hal ini sesuai dengan acuan pustaka yang menyatakan bahwa struma non-toksik dapat menyerang kelompok usia mana saja, walaupun terjadi paling sering pada beberapa golongan usia tertentu tergantung pada jenis dari perubahan anatomi struma non-toksik tersebut. $^{11,12}$ Walaupun terlihat sporadik, dapat dilihat angka kejadian struma nontoksik nodusa cenderung meningkat dengan bertambahnya usia dan cenderung mencapai puncak di decade ke 3 dan 4 yang menunjukkan bahwa risiko terjadinya struma non-toksik nodusa akan bertambah sejalan dengan usia terlebih pada populasi dengan berusia $>40$ tahun yang sering dikaitkan dengan sistem imun tubuh yang mulai menurun. ${ }^{5,13}$ Sumber-sumber lain melaporkan angka kejadian struma non toksik difusa paling banyak terjadi pada usia pubertas dan dewasa muda dikarenakan kebutuhan yang meningkat pada masa tersebut terlebih pada populasi perempuan dan cenderung menurun dengan bertambahnya usia. Hal yang berbeda juga dilaporkan dengan penderita terbanyak berada pada usia $>40$ tahun. ${ }^{4,12,14} \mathrm{Hal}$ ini mungkin terjadi karena struma non-toksik difusa tidak bergejala secara klinis, sehingga penderita cenderung mencari pengobatan setelah terjadi kompresi pada saluran napas atau untuk kebutuhan kosmetik. $^{1}$

Pada penelitian ini, berdasarkan Tabel 3 yaitu distribusi perubahan anatomi penderita yang terbanyak ialah struma nontoksik uninodusa $(36,8 \%)$ disusul dengan struma non-toksik multinodusa $(34,2 \%)$, struma non-toksik nodusa yang tidak 
digolongkan menjadi multinodusa atau uninodusa $(15,8 \%)$, dan struma non-toksik difusa $(13,2 \%)$. Pada penelitian ini, didapatkan bahwa struma non-toksik kedua terbanyak di RSUP Prof. Dr. R. D. Kandou Manado ialah struma non-toksik multinodusa. Sampai saat ini penyebab terjadinya struma non-toksik multinodusa sendiri masih belum diketahui, walaupun beberapa bukti menyatakan dapat dikaitkan dengan kurangnya asupan yodium dan faktor genetik. Di sisi lain, kurangnya asupan yodium menjadi penyebab utama struma non-toksik difusa. ${ }^{2,4}$ Kurangnya penderita struma non-toksik difusa mungkin dapat dikaitkan dengan kebijakan pemerintah untuk memperbaiki asupan yodium dalam Keputusan Presiden Republik Indonesia nomor 69 tahun 1994 tentang pengadaan garam beryodium.

Berdasarkan Tabel 4 yaitu distribusi menurut kelas rawat inap pederita struma non toksik dapat dilihat pasien paling banyak dirawat di kelas III $(44,8 \%)$. Hal ini mungkin dapat dikaitkan dengan kemungkinan bahwa populasi yang menempati kelas VIP ialah golongan status ekonomi menengah ke atas, kelas I dan II golongan status ekonomi menengah, dan kelas III status ekonomi menengah ke bawah. Hal ini sesuai dengan acuan pustaka bahwa penyakit ini ditemukan lebih banyak pada sosioekonomi rendah yang dihubungkan dengan kurangnya pengetahuan, konsumsi yodium, dan kebiasaan merokok. ${ }^{7,10}$

Struma tetap cenderung ditemukan pada sosioekonomi rendah walaupun pada populasi dengan asupan yodium yang cukup dan konsumsi sumber air yang sama dengan populasi sosiekoomi yang baik, hal ini dikarenakan karena kurangnya asupan gizi populasi tersebut. Sebuah penelitian memperlihatkan buruknya diet protein pada tikus dapat menggangu transportasi dari yodium, menurunkan konsentrasi dari hormon kelenjar tiroid, dan membesarnya kelenjar tiroid. ${ }^{15}$

Berdasarkan Tabel 5 yaitu distribusi tempat tinggal penderita struma non-toksik terdapat 18 kasus $(68,4 \%)$ bertempat tinggal di dataran rendah dan 18 kasus $(31,6 \%)$ bertempat tinggal di dataran tinggi. Penderita struma non-toksik cenderung ditemukan bertempat tinggal di dataran tinggi karena kurangnya kandungan yodium pada air dan udara di dataran tinggi. ${ }^{5}$ Hal ini mungkin, dapat dikaitkan dengan distribusi perubahan anatomi struma non-toksik pada penderita di RSUP Prof. Dr. R. D. Kandou yang lebih banyak terserang struma non-toksik uninodusa dan struma non-toksik multinodusa; keduanya termasuk dalam struma non-toksik nodusa. Penyebab struma non-toksik nodusa sendiri masih belum diketahui pasti walaupun telah dilaporkan pada beberapa kasus bahwa kekurangan yodium turut berperan dalam penyakit ini. ${ }^{14}$ Berbeda halnya dengan struma non-toksik difusa dengan etiologi yang telah diketahui secara pasti yaitu kurangnya asupan yodium. ${ }^{1,5,16}$ Pada penelitian ini, dari 5 penderita struma non toksik difusa ternyata lebih banyak yang bertempat tinggal di dataran tinggi dibandingkan di dataran rendah walaupun hanya selisih 1 penderita.

Berdasarkan Tabel 6 yaitu distribusi pemeriksaan laboratorium didapatkan hasil 61 kasus $(81,3 \%)$ dengan eutiroid, 3 kasus (4\%) dengan hipotiroid, dan 11 kasus $(14,7 \%)$ dengan hipertiroid. Hasil ini sesuai dengan teori yang menyatakan bahwa mayoritas penderita struma non-toksik tidak mengalami perubahan secara fisiologik dan klinis, meskipun tidak menutup kemungkinan terjadinya hipertiroid atau hipotiroid namun perbedaan dengan nilai normal tidak akan banyak berbeda. Hal ini dikarenakan tubuh masih bisa mengompensasi kekurangan yodium dengan pembesaran kelenjar tiroid. ${ }^{17}$

Berdasarkan Tabel 7 yaitu distribusi pengobatan yang diterima pasien didapatkan 31 kasus $(81,6 \%)$ diterapi dengan tindakan operatif, 1 kasus $(21,6 \%)$ non-operati,f serta 6 kasus $(15,8 \%)$ tidak diterapi. Kemungkinan pasien lebih banyak datang dengan kondisi yang sudah lanjut dikarenakan tidak adanya gejala-gejala yang dirasakan seperti pada penyakit struma toksik dan belum adanya kompresi 
pada saluran napas yang dialaminya sehingga pasien cenderung mengulur waktu untuk datang berobat. Tindakan operatif juga dapat dilakukan untuk kosmetik walaupun tanpa adanya gangguan saluran pernapasan. $^{1,17}$

\section{SIMPULAN}

Dari hasil penelitian desktiptif retrospektif pada 38 kasus struma non toksik yang dirawat di RSUP Prof. Dr. R. D. Kandou Manado periode Juli 2014- Juni 2016 dapat disimpulkan bahwa majoritas terdiri dari perempuan, usia 41-50 tahun, diagnosis struma non-toksik uninodusa, golongan ekonomi menengah ke bawah, tempat tinggal di dataran rendah, hasil pemeriksaan laboratorium cenderung eutiroid, dan terapi tindakan operatif.

\section{SARAN}

1. Perlu pengisian rekam medik yang lengkap.

2. Edukasi kepada masyarakat tentang penyakit struma non toksik.

3. Penelitian lebih lanjut mengenai etiologi serta hubungan ketinggian dataran dengan kejadian struma non toksik.

\section{DAFTAR PUSTAKA}

1. Isselbacher KJ, Braunwald E, Wilson JD, Martin JB, Fauci AS, Kasoer DL. Prinsip-Prinsip Ilmu Penyakit Dalam Jilid 5 (13th ed). Asdie AH, translator. Jakarta: EGC, 1994; p. 2144.

2. Kumar V, Cotran RS, Robbins SL. Buku Ajar Patologi Jilid 2 (7th ed). Pendit BU, Alih Bahasa. Jakarta: EGC, 2004; p. 815-7.

3. Assagaf SM, Lumintang $N$, Lampus $H$. Gambaran eutiroid pada pasien struma multinodusa non-toksik di Bagian Bedah RSUP Prof. Dr. R. D. Kandou Manado periode Juli 2012-Juli 2014. eCl. 2015;3:758-62.

4. Shahrani SA, Metwally AE, Surimi KA, Salih BS, Saleh Y, Shehri AA, et al. The epidemiology of thyroid diseases in the Arab World; a systematic review. Academic Journal. 2016;8(2):17-26.

5. Li M, Eastman CJ. Jurnal atau apa? The changing epidemiology of iodine deficiency. Nat Rev Endocrinol. 2012;8)7):434-40.

6. Santoso M, Ndraha S, Pattipawae H, Bayu B, Doranggi R. Pola penyakit struma di RSUD Koja. Meditek. 2004;12:1013.

7. Hegedüs L, Brix TH, Paschke R. Etiology of simple goiter. Thyrooid. 2009;19(3):209-11.

8. Weber G, Vigon MC, Stroppa L, Chiumello G. Thyroid function and puberty. MedLine. 2003;2:253-7.

9. Kundra P, Burman KD. The effect of medications of thyroid function tests. Med Clin North Am. 2012;96(2):28395.

10. Kota Manado, Kota ujung Sulawesi. Available from: www. Gocelebes.com

11. Lee SL, Ananthakrishnan S, Talavera F, Wehmeier K, Griffing GT, Gambert SR. Nontoxic goiter. Medscape [internet]. 2013. Available from: http://emedicine.medscape.com/ article/120392-overview

12. Setiati S, Alwi I, Sudoyo AW, Simadibrata M, Setyohadi B, Syam AF. Buku Ajar Ilmu Penyakit Dalam. Jakarta: Interna Publishing, 2014; p. 2464-72.

13. Unknown. Goiter. Cleaveland Clinic. [internet]. 2015. Available from: http://my.clevelandclinic.org/health/dis eases_conditions/hic-goiter

14. Gabrielyan A. Why are women more likely to have thyroid disease than men?. News. Am. [internet]. 2012. Available from: https://med.news.am/eng/news/ 1155/why-are-women-more-likely-tohave-thyroid-disease-than-men.html

15. Knudsen N, Bulow I, Lauberg P, Ovesen L, Perrild H, Jergensen T. Low socio-economic status and familial occurrence of goitre are associated with a high prevalence of goitre. Eur $\mathrm{J}$ Epidemiol. 2003;18(2):175-81.

16. Hughes K, Eastman C. Goiter - causes, investigation and management. Aus Fam Physician. 2012;41(8):572-6.

17. Longo LD, Dennis LK, Jameson JL, Fauci AS, Hauser SL, Loscalzo J. Harrison's Principles Internal Medicine volume 2 (18th edition). United States of America: The McGraw-Hill Company, 2012; p. 2930-2932. 